\title{
POLISEMI DALAM KITAB INJIL LUKAS BERBAHASA ALUNE
}

\author{
Noce Aimoly \\ Universitas Pattimura \\ e-mail: noceaimoly@gmail.com
}

\begin{abstract}
Abstrak: Penelitian ini bertujuan mendeskripsikan polisemi dalam Kitab Injil Lukas berbahasa Alune yang menjelaskan empat kelas kata dasar dan turunan berdasarkan kajian semantik. Penelitian menggunakan penelitian deskriptif kualitatif yang mendeskripsikan data secara alamiah berdasarkan teori. Dari 22 ayat firman Tuhan dalam Kitab Injil Lukas berbahasa Alune peneliti hanya menggunakan beberapa kosakata yang dianggap memiliki makna ganda (berpolisemi) sebagai bahan kajian berdasarkan kelas kata nomina, pronomina, verba, dan adjektiva. Hasil penelitian menujukan bahwa ternyata kasus polisemi bukan saja terjadi pada katakata yang berbahasa Indonesia saja seperti kata kaki yang bermakna kaki gunung, kaki manusia, kaki meja dan lain sebagainya melaingkan dalam bahasa Alune pun mengalami hal serupa seperti ai yang bermakna "kayu, salib, dan pentung".
\end{abstract}

Kata Kunci: Polisemi, Kitab Injil Lukas, bahasa Alune 


\title{
THE POLYGLOT FROM THE BOOK OF LUKE SPEAKS ALUNE
}

\author{
Noce Aimoly \\ Universitas Pattimura \\ e-mail: noceaimoly@gmail.com
}

\begin{abstract}
: the study set out to descroibe the polisemi in the Alune bible of luke and the four class languanges of the rood and derivation based on a semantic study. Studies use descriptive research that points date naturally based on theory. From the 22 verses of the lord's words in the Alune gospel of luke, a researcher has usual only a few words thas are thought to have dual meanings (polygamous) meaning for studies based on noun, pronomine, verb, and adjective classes. Studies suggest that the use of polysemy is not confiued to Indonesian words like meaning ful foot work a human leg, table leg and so forth but in the Algerian language also experlenced something similar like al that mean's "wood, cross and club".
\end{abstract}

Key words: the politic in Alune bible of luke. 


\section{A. PENDAhULUAN}

Kata semantik dalam bahasa Indonesia (Inggris: semantics) berasal dari bahasa Yunani sema (kata benda yang berarti "tanda" atau "lambang". Kata kerjanya adalah semaino yang berarti "menandai" atau "melambangkan". Yang dimaksud dengan tanda atau lambang disini, sebagai padanan kata sema itu adalah tanda linguistik (Prancis: signe linguistique) seperti yang dikemukakan oleh Ferdinand de Saussure 1966 (dalam Chaer 2012:2), yaitu yang terdiri dari [1] komponen yang mengartikan, yang berwujud bentuk-bentuk bunyi bahasa. [2] Komponen yang diartikan atau makna dari komponen yang pertama itu. Kedua komponen ini adalah merupakan tanda atau lambang; sedangkan yang ditandai atau dilambangkan adalah sesuatu yang berada di luar bahasa yang lazim di- sebut referen atau hal yang ditunjuk.

Semantik kemudian disepakati sebagai istilah yang digunakan untuk bidang linguistik yang mempelajari hubungan antara tanda-tanda linguistik dengan hal-hal yang ditandainya. Dengan kata lain, bidang studi dalam linguistik yang mempelajari makna atau arti dalam bahasa, oleh karena itu, kata semantik dapat diartikan sebagai ilmu tentang makna atau tentang arti, yaitu salah satu dari tiga tataran analisis bahasa, fonologi, gramatika, dan semantik (Chaer,2012:2). Demikian dapat disimpulkan bahwa semantik mengandung pengertian studi tentang makna dengan anggapan bahwa makna menjadi bagian dari bahasa, maka semantik merupakan bagian dari linguistik.

Sebagai alat interaksi sosial peranan bahasa besar sekali, hampir tidak ada kegiatan manusia yang berlangsung tanpa kehadiran bahasa. Bahasa muncul dan diperlakukan dalam segala kegiatan seperti pendidikan, perdagangan, keagamaan, politik, militer, dan sebagainya. Bahasa telah memudahkan dan memperlancar semua kegiatan itu dengan baik, kita tidak bisa membayangkan bagaimana keadaan masyarakat manusia ini bila tidak ada bahasa. Sepi dan interaksi sosial juga akan banyak mengalami hambatan, mengapa bahasa begitu besar peranannya dalam kehidupan manusia?. Karena bahasa mampu mentransfer keinginan, gagasan, kehendak, dan emosi seorang manusia kepada manusia lainnya. Bahasa yang wujudnya berupa bunyi-bunyi ujar dalam suatu pola bersistem tidak lain dari pada lambang-lambang konsep dan gagasan yang dipahami dan disepakati bersama oleh para anggota penuturnya.

Sudah disebutkan pada bagian sebelumnya bahwa objek studi semantik adalah makna; atau lebih tepat makna yang terdapat dalam satuan-satuan ujaran seperti kata, frase, klausa, dan kalimat. Untuk dapat memahami apa yang disampaikan penutur, perlu mencermati setiap kata dalam tuturan pembicara (pemberi informasi lisan) dengan baik. Sehinga ketika kita menyampaikan informasi yang sama dari penutur satu ke penutur lainnya masih memiliki makna yang sama. Untuk dapat memahami 
apa yang disebut makna atau arti, kita perlu menoleh kembali kepada teori yang dikemukakan oleh Ferdinand de Saussure, bapak linguistik modern. Menurut de Saussure setiap tanda linguistik terdiri dari dua unsur, yaitu [1] yang diartikan (Prancis : signified) dan [2] yang mengartikan (Prancis: signfiant, inggris: signifier). Yang diartikan (signifie' signified) sebenarnya tidak lain dari pada konsep atau makna dari sesuatu tanda bunyi.

Hubungan antara kata dengan maknanya, seperti sudah diulas bahwa bersifat arbitrer. Artinya tidak ada hubungan wajib antara deretan fonem pembentuk kata itu dengan maknanya namun, hubungan bersifat konvensional. Artinya disepakati oleh setiap anggota masyarakat suatu bahasa untuk mematuhi hubungan itu; sebab kalau tidak, komunikasi verbal yang dilakukan akan mendapat hambatan. Karena itu, dapat dikatakan, secara sinkronis hubungan antara kata dengan maknanya (atau lebih tepat lagi: makna sebuah kata) tidak akan berubah. Secara diakronis ada kemungkinan bisa berubah sesuai dengan perkembangan budaya dan masyarakat yang bersangkutan. Misalnya, kata dapat memahami bahwa referen kata kaki adalah kaki anggota tubuh manusia (juga binatang); tetapi bagaimana dengan referen kata kaki pada bentuk kaki gunung, atau kaki meja?. Menurut Verhaar, referen kata kaki tetap kaki sebagai anggota tubuh manusia dan bukan pada sesuatu yang lain seperti pada gunung atau meja. Pada bentuk kaki gunung dan kaki meja, kata kaki digunakan atau dipakai untuk merujuk pada sesuatu yang lain secara metaforis, secara perbandingan. Salah satu ciri makna kaki, yaitu terletak di sebelah bawah, diperbandingkan dengan bagian bawah dari gunung itu.

Chaer (2006 : 386) mengatakan bahwa polisemi adalah kata-kata yang maknanya lebih dari satu, sebagai akibat terdapatnya lebih dari sebuah komponen konsep makna pada kata-kata tersebut. Dikatakan bahwa dalam kasus polisemi, biasanya makna pertama (pada entri dalam kamus) adalah makna sebenarnya, makna leksikalnya, makna denotatifnya, atau makna konseptualnya. Yang lain adalah makna-makna yang dikembangkan berdasarkan salah satu komponen makna yang dimiliki kata atau satuan ujaran itu.

Bertolak dari uraian tersebut, apakah keadaan kebahasaan semacam itu juga terjadi di dalam Alkitab berbahasa Alune? Ya, berdasarkan pengertian polisemi yang disampaikan oleh Chaer di atas dengan demikian menggugah hati peneliti untuk meneliti permasalahan yang ada pada Alkitab berbahasa Alune. Untuk menjelaskan kepada pembaca sehingga pembaca tidak salah memahami, makna yang tertulis di dalam Alkitab berbahasa Alune ini. Serta memberikan pemahaman kepada masyarakat, bahwa bahasa Alune merupakan bahasa yang unik dan membuat masyarakat mudah tidak merasa malu untuk memakai, serta mewarisinya kepada generasi selanjutnya. Untuk mengetahui hal tersebut, perlu diadakan penelitian lebih lanjut tentang polisemi dalam Alkitab berbahasa Alune. Penelitian ini peneliti 
mengkaji Alkitab Perjanjian Baru yakni, Injil Lukas berbahasa Alune. Hal ini disebabkan oleh, peneliti menemukan kosakata yang sama maknanya (Polisemi), dalam Alkitab Injil Lukas berbahasa Alune. Diharapkan mampu membuat para pembaca tidak merasa bingung, dan dengan cepat memahami konteks makna yang tertera dalam Alkitab tanpa menghilangkan makna sebenarnya, dalam Firman Tuhan yang disampaikan dalam Alkitab berbahasa Alune.

Berikut adalah penerapan polisemi dalam Injil Lukas pada kata esi. Kata esi memiliki tiga (3) makna yang dapat kita pahami jika kita membaca Kitab Injil Lukas. Berikut ini contoh kalimat yang menjelaskan kata esi. (Lukas 1:21, 1:48, dan 4:1).

Contoh kalimat:

1. Esi noake be mula pine zakaria itakwali kuate me Tuhane lumare?

Mereka bertanya bahwa mengapa sampai sakaria terlalu lama dalam Bait Suci Tuhan?.

2. Esi beteke bei meije eti pelare pusue tamata beteke be Alla aono misete elake eteku.

Aku berkata: mulai dari sekarang sampai selamanya semua orang mengatakan bahwa Allah telah membuat kebaikan besar atas kita.

3. Mahlabai re Esi saploeke, leke amu lelale kena batu yake.

Engkau akan dipegang (ditata) sehingga kakimu tidak terantuk batu.

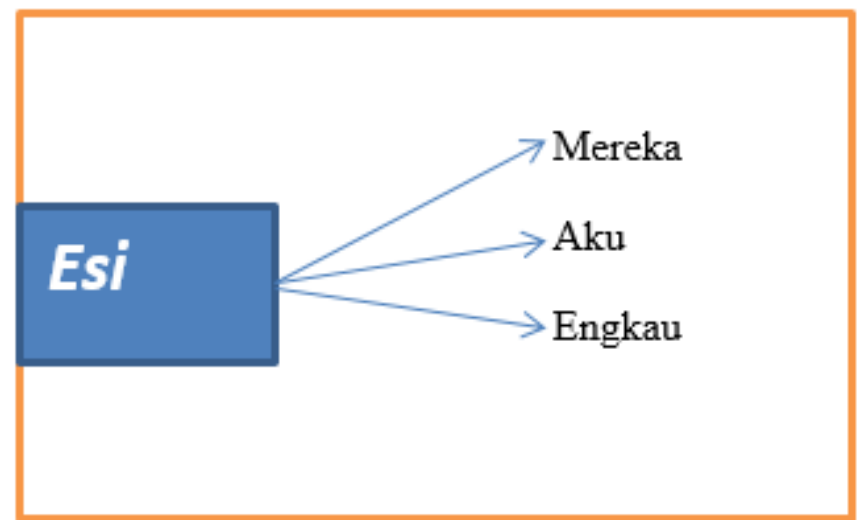

Polisemi pronomina esi merupakan kata berbahasa Alune yang tidak mengalami proses afiksasi, dengan demikian kata esi diposisikan sebagai bentuk kata dasar yang memiliki tiga makna, diantaranya: [1] mereka [2] aku, dan [3] engkau. Kata esi dalam bahasa Alune bermakna "mereka" dengan demikian dapat dikatakan bahwa kata esi yang bermakna "engkau" merupakan acuan dalam bahasa Alune, karena kata 
tersebut tidak ditemukan penggunaan kosakatanya. Sedangkan kata esi yang bermakna "aku" dapat ditemukan kosakatanya yakni kata au. Namun, polisemi dari kata esi yang bermakna "aku" dapat diposisikan sebagai penggunaan kosakata esi, dapat diketahui penggunaannya dalam kalimat berbahasa Alune.

Penulis Injil Lukas bukanlah seorang Yahudi maupun salah satu dari kedua belas rasul. Ia adalah seorang Yunani dan menunjukan Injilnya kepada seorang pria yang juga seorang Yunani. Para ahli teologia meyakini bahwa Lukas menemui Maria ibu Yesus, Yakobus saudara Yesus, dan beberapa saksi mata lainnya sebagai narasumber saat ia melakukan penelitiannya dan menulis Injilnya. Paulus menyebut Lukas sebagai "tabib yang kekasih" dan teman seperjalanan. Sudah jelas bahwa Lukas melakukan perjalanan dengan Paulus untuk mengobati gejala-gejala fisik dari “ duri dalam daging" sang rasul ini (2 korintus 12). Paulus menyebut nama Lukas sebanyak tiga kali dalam surat-suratnya yang penuh dengan inspirasi ini (Kolose 4:14, 2 Korintus 4:11, dan Filemon 24).

Penulis ini adalah seorang yang sangat berpendidikan. Pada masa kini, ia akan disebut sebagai seorang ilmuwan. Ia menggunakan lebih banyak istilah-istilah medis dibandingkan Hipokrates, sang "bapak medis modern”, serta memakai tata bahasa Yunani terbaik dibandingkan semua penulis perjanjian baru lainnya, termasuk Paulus. Lukas adalah seorang penulis berbakat dan seorang ahli sejarah yang sangat akurat.

Kitab Injil Lukas menjadi kesukaan bagi banyak orang sebab Kristus yang digambarkan oleh Lukas adalah seorang yang sangat pengasih, penuh belas kasihan, penuh perhatian, dan sangat mengena dengan sisi kemanusiaan kita. Sebagai seorang tabib, Lukas memiliki nurani sosial yang besar juga. Dengan selalu menekankan pada sentuhan manusiawi, Lukas menuliskan bahwa Marta menjadi marah karena Maria tidak ikut mempersiapkan dan melayani saat Yesus menjadi tamu makan malam mereka (Lukas 10:38-42). Dengan mata seorang ahli sejarah yang akurat serta hati seorang tabib yang penuh belas kasihan, Lukas adalah orang yang membritahu kita bahwa mata Yesus memandang persis ke mata Petrus saat ayam berkokok dan Petrus baru saja menyangkal Tuhannya sebanyak tiga kali (Lukas 22;60-61).

Sou Misete bei alla kena Yesuse (kabar sukacita dari Allah ketika Yesus lahir) merupakan Kitab suci Agama Kristen, yang diterbitkan oleh Gereja Protestan Maluku pada tahun 2012, dalam rangka menyamaratakan, melestarikan, dan mengingat kembali setiap budaya milik masyarakat adat di Maluku. Kitab berbahasa Indonesianya, yang telah di artikan ke dalam Bahasa Alune ini, merupakan hasil dari gumulan besar Gereja Protestan Maluku tentang Agama dan Budaya kolektif yang ada ditengah-tengah masyarakat Maluku. Hal ini di lakukan agar setiap ajaran agama yang diajarkan dapat dipahami, dan dimaknai secara mendalam oleh masyarakat 
karena bahasa yang dipakai dapat dimengerti oleh masyarakat penutur dan orangorang yang ingin mempelajari bahasa Alune (Pdt Chr J. Ruhulessin 2006:1). Kitab Suci Agama Kristen yang di artikan ke Bahasa Alune ini, akan kita temuai dalam bentuk nyanyian Kidung Jemaat atau nyanyian Gerejawi yang telah diartikan kedalam bahasa suku Alune, selain Kitab Perjanjian Baru ada juga yang Perjanjian Lama berbahasa Alune.

Bahasa Alune adalah salah satu bahasa daerah dari 123 bahasa daerah di Provinsi Maluku. Bahasa Alune merupakan bahasa terbesar di antara bahasa- bahasa di Pulau Seram. Bahasa Alune dituturkan di 26 Desa di tiga kecamatan di Seram Barat, Maluku tengah. 5 (lima) desa di Kecamatan Seram Barat, 10 (sepuluh) Desa di Kecamatan Kairatu, dan 11 (sebelas) Desa di Kecamatan Taniwel (Makaruku 1998:2).

Berdasarkan latar belakang di atas maka yang menjadi permasalahan dalam penelitian ini adalah: bagaimanakah Polisemi dalam Alkitab Injil Lukas Berbahasa Alune?.

Tujuan dari penelitian ini adalah: mendeskripsikan Polisemi dalam Alkitab Injil Lukas Berbahasa Alune.

\section{B. METODE PENELITIAN}

Penelitian ini bersifat kualitatif yaitu penelitian yang menggunakan latar alamiah dengan maksud menafsirkan fenomena yang terjadi dengan melibatkan berbagai metode yang ada. Denzin dan Lincoln (dalam Moleong 2008: 5). Jadi dalam penelitian ini penulis mendeskripsikan secara alamiah yakni penggunaan kata bermakna ganda (Polisemi), dalam Alkitab berbahasa Alune yang diterbitkan oleh Lembaga Gereja Protestan Maluku (GPM).

Bogdan dan Biklen dalam Moleong (2008:8-11), penelitian kualitatif setidaktidaknya mempunyai karakteristik sebagai berikut:

1. Manusia sebagai instrumen penelitian. Dalam konteks ini manusia bermanfaat untuk menangkap serta memahami kata yang bermakna ganda (polisemi) dari bahan bacaan dalam Alkitab berbahasa Alune. Manusia dikatakan sebagai instrumen penelitian sebab ia merupakan perencana, pelaksana, pengumpulan data, dan pada akhirnya ia menjadi pelapor hasil penelitian;

2. Penelitian bersifat deskriptif yaitu peneliti memecahkan masalah yang benar-benar terjadi berdasarkan data-data serta menganalisis dan menginterpretasi.

3. Data yang dikumpulkan cenderung berbentuk kata-kata atau gambaran dari pada angka-angka. Dalam penelitian ini, data yang dikumpulkan berupa kosakata polisemi

pronomina, verba, nomina dan preposisi yang terdapat dalam Alkitab Injil Lukas berbahasa Alune. 
4. Analisis data cenderung bersifat induktif. Hal ini dilakukan agar mempermudah pendeskripsian konteks yang muncul setelah penelitian sebelumnya dan membuat abstraksi yang disusun berdasarkan bukti-bukti yang terkumpul. Dalam penelitian ini, penulis membuat pendeskripsian pemikiran dari data kosakata pronominal, verba, nomina, dan preposisi bahasa Alune, yang terdapat dalam Alkitab. Pendeskripsian dimulai dari data khusus ke data umum.

Data penelitian ini adalah data yang berwujud kata-kata yang mengandung makna polisemi. Sedangkan sumber data dalam penelitian ini adalah kitab Injil Lukas Perjanjian Baru berbahasa Alune terbitan Gereja Protestan Maluku (GPM) tahun 2012.

\section{PEMBAHASAN}

Hasil kajian pada Kitab Injil Lukas pasal 1-24 berbahasa Alune, peneliti menemukan empat jenis kata yang memiliki bentuk dasar dan bentuk turunan dalam pemaparan kalimatnya. Dengan demikian dalam penelitian ini, peneliti akan menguraikan apa yang dimaksud dengan polisemi berbahasa Alune berdasarkan bentuk kata dasar dan bentuk kata turunannya, dalam empat kelas kata yakni: Kelas kata pronomina, verba, nomina, dan preposisi. Berikut ini akan diuraikan kasus polisemi berdasarkan kelas kata dan bentuknya dari ALkitab Injil Lukas berbahasa Alune.

1. Polisemi Pronomina esi

Polisemi Pronomina dasar esi berbahasa Alune memiliki tiga macam makna. Ketiga macam makna yang dimaksud adalah sebagai berikut [1] mereka, [2] aku, dan [3] engkau. Hal ini tercantum dalam polisemi pronomina dasar dari kata esi, yang mempunyai hubungan kepolisemian yang dapat dilihat pemakainnya pada kutipan berikut ( Lukas 1:21, 1:48, dan 4:1).

Contoh kalimat :

1. Esi noake be mula pine zakaria itakwali kuate me Tuhane lumare?

Mereka bertanya bahwa mengapa sampai sakaria terlalu lama dalam Bait Suci Tuhan?.

2. Esi beteke bei meije eti pelare pusue tamata beteke be Alla aono misete elake eteku.

Aku berkata: mulai dari sekarang sampai selamanya semua orang mengatakan bahwa Allah telah membuat kebaikan besar atas kita.

3. Mahlabai re Esi saploeke, leke amu lelale kena batu yake.

Engkau akan dipegang sehingga kakimu tidak terantuk batu. 


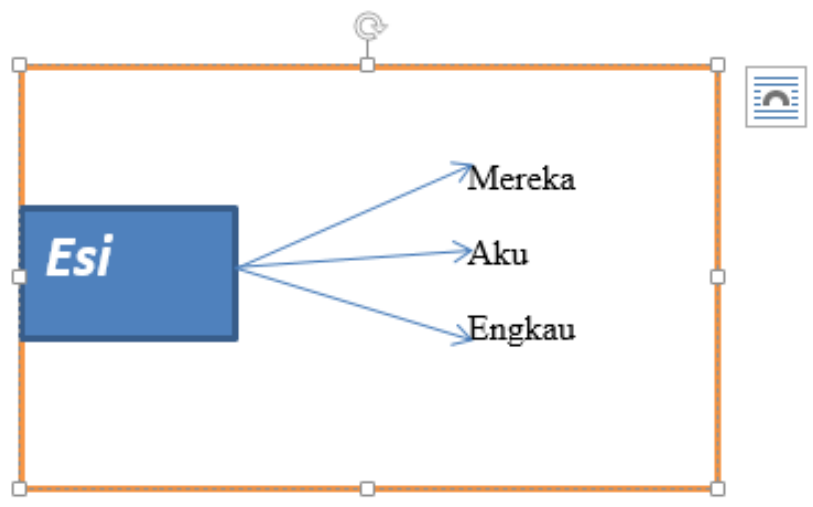

Polisemi pronomina esi merupakan kata berbahasa Alune yang tidak mengalami proses afiksasi, dengan demikian kata esi diposisikan sebagai bentuk kata dasar yang memiliki tiga makna, diantaranya: [1] mereka [2] aku, dan [3] engkau. Kata esi dalam bahasa Alune bermakna "mereka" dengan demikian dapat dikatakan bahwa kata esi yang bermakna "engkau" merupakan acuan dalam bahasa Alune, karena kata tersebut tidak ditemukan penggunaan kosakatanya dalam Kitab Injil Lukas berbahasa Alune. Sedangkan kata esi yang bermakna "aku" dapat ditemukan kosakatanya yakni kata au. Namun, polisemi dari kata esi yang bermakna "aku" dapat diposisikan sebagai penggunaan kosakata esi, dapat di ketahui penggunaannya dalam kalimat berbahasa Alune.

a. Polisemi nomina kuele.

Polisemi nomina dasar kuele memiliki dua macam makna kata, berikut makna-makna dari polisemi nomina dasar kuele; [1] air, [2] sungai. Hal ini

tergambar pada kata kuele dalam uraian yang memiliki hubungan kepolisemian nomina dasar pada kutipan kalimat berikut (Lukas 3:16, 4:1).

Contoh Kalimat:

4. Au baptise imi kena kuele po iono Ro misete ikbasae laleimu.

Aku membaptiskan kau

dengan air, tetapi Roh Tuhan memberkatimu

5. Yesuse ileu bei kuele yordane, Ro misete ikbasaeni ktili titinai rame. '

Yesus pulang dari sungai Yordan, Roh Tuhan ada padanya. 


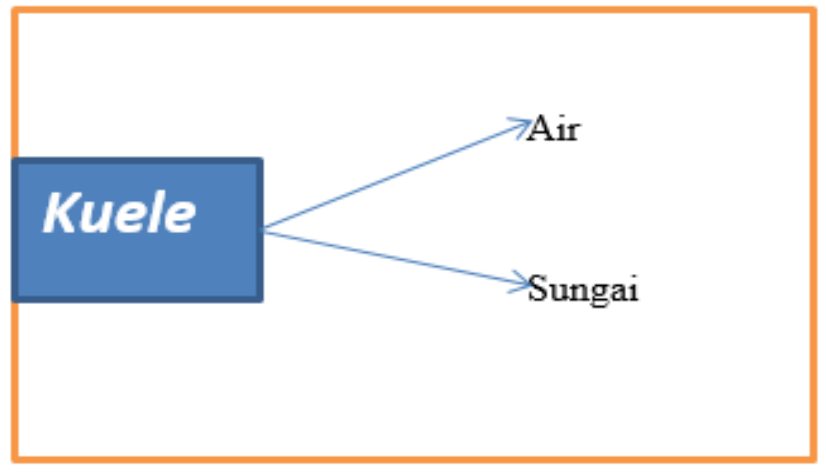

Kuele merupakan polisemi Nomina Dasar yang maknanya iyalah "air" . Air dari konteks kalimat yang berasal dari kata kuele yang terdapat dalam Injil Lukas, mengkisahkan "air" sebagai simbol pada pengajaran Yesus di daerah Yordan tersebut. Polisemi nomina dasar kuele bukan saja bermakna "air" melaingkan "sungai" juga. Pada hakikatnya "air" dan "sungai" iyalah dua jenis yang sama, namun dapat dilihat perbedaanya pada tempat dimana "air" dan "sungai" itu di kontekskan. Setelah penjabaran konteks "air" dalam Kitab Injil Lukas berbahasa Alune di atas, berikut konteks "Sungai" yang terdapat dalam kalimat dari Firman Injil Lukas berbahasa Alune. "Sungai" pada konteksnyaiyalah air deras yang mengalir menyusuri lereng bukit dan daerah dataran dari hulu sampai ke hilirnya. Dalam Injil Lukas "sungai Yordan" merupakan air yang mengalir di sekitar daerah itu, ketika itu Yohanes Pembatis (orang yang diutus Allah) membaaptis Yesus (Ritual Agama Kristen) di "sungai" tersebut.

Berdasarkan konteks dari penjelasan tentang polisemi kuele yang bermakna "air" dan "sungai" di atas, dapat disimpulkan bahwa: "air" dan "sungai" merupakan dua bentuk yang sama, namun tempat untuk benda itu beradah berbedah. "Air" pada konteks data 12 merupakan "air" yang berada pada suatu wadah kecil yang tertampung. Sedangkan pada data 13 "air" yang dimaksudkan iyalah "air" yang mengalir deras menyusuri daerah Yordan dari hulu sampai ke hilirnya atau biasa dituturkan dengan kata "sungai".

\section{b.Polisemi Verba rana}

Polisemi verba dasar rana berbahasa Alune memiliki empat macam makna di antaranya: [1] merampas, [2] memetik, [3] merampok, dan [4] ambilah. Hal yang tergambar dalam uraian yang memiliki hubungan kepolisemian hal ini, dapat dilihat penggunaan kalimatnnya pada kutipan berikut: (Lukas 3;14, 6:44, 10:30, dan 15:23).

Contoh Kalimat :

6. Yohanese iombe, "imi rana tamata makete esi yelu palani yake.

Yohanes berkata: janganlah kalian merampas barang milik orang lain.

7.Le bei ai aini nluline tamata esi rana ara buai kai anggure buai mei mo.

Karena dari pohon yang berduri, orang tidak memetik buah ara dan buah anggur. 
1. Eleki kena ime lalane tlai, tamata ndeanaru esi rana pusue eni taneyaru kai lapune me nanakwalaije.

Kemudian ketika dia ditengah perjalanan pencuri datang, mereka merampok semua barang termasuk baju di badanku.

2. Kai rana sape anai nkopane eleki bunue le ami lalema ndina titinai hoko ami kane sakesa mina.

Dan ambilah lembu sapi yang gemuk lalu menyembelihnya. Supaya hati kita bersukacita dan dapat makan bersama.

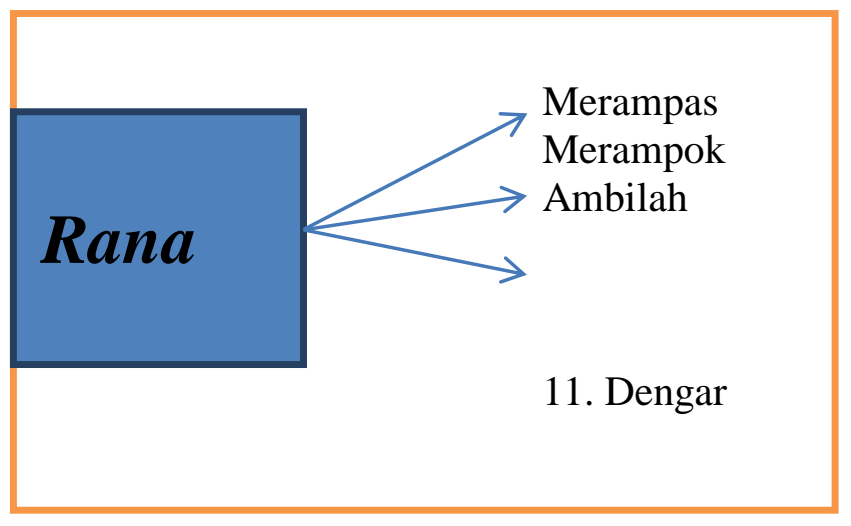

Rana maknanya "ambil", adalah kata berbahasa Alune yang memiliki tiga makna dalam Kitab Injil Lukas berbahasa Alune, di antaranya: data 18 merampas, data 19 merampok, dan data 20 ambil. Dari ketiga makna tersebut dua di antara makna data 18 dan 19, merupakan afiksasi pada sufiks dan infiks $\{m e-k a n\}$ dari kata dasar \{rupa dan rampas\}. Berikut ini konteks yang melatarbelakangi ketiga makna dari polisemi rana pada tabel 4.7 di atas. Konteks pada makna "merampok" dalam kitab Injil Lukas berbahasa Alune iyalah, saat Yohanes memberitakan kepada orang banyak yang mendengarkan pengajarannya tentang Allah, bahwa janganlah kita "merampas" barang milik orang lain. Konteks ke dua dari data 19 iyalah tentang makna "merampok", kisah dari makna merampok adalah, ketika Yesus mengajarkan kepada orang banyak tentang seorang Samaria yang baik hati, pada konteks tersebut Yesus mengajarkan dengan perumpamaan bahwa diriNya hendak melakukan perjalanan dan dirampok oleh orang tidak di kenalnya termasuk mengambil pakaian di badaNya.

Dari ketiga makna dari konteks polisemi rana di atas menjelaskan bahwa sebenarnya "merampok" dan "merampas" adalah suatu kegiatan mengambil barang milik orang lain, namun merampok dan merampas iyalah perbuatan yang tidak terpuji karena mengambil dengan tidak meminta izin dari pemiliknya. Dapat kita simpulkan bahwa kata rana iyalah polisemi (kata bermakna ganda) karena memiliki makna lebih dari satu. 
c.Polisemi Preposisi kena

Polisemi preposisi dasar kena memiliki tiga macam makna, yakni, [1] dengan [2] pada, [3] untuk. Hal yang tergambar untuk membuktikan ketiga makna dari polisemi kena ini memiliki hubungan kepolisemian dapat dilihat pada kutipan kalimat berikut: (Lukas 16:20, 17:2, 18:10).

Contoh Kalimat:

10. Nanakwalaije penu kena oana

Tubuhnya penuh dengan kotoran.

11. Imi supu hukumane lake titinai, lesi bei esi lo imi mokane kena batu elake eleki poiemi lope meite nanuke eleki bature molo le imi.

Kalian akan mendapatkan hukuman lebih sulit, lebih dari mereka yang mengikat lehernya pada batu dan membuangnya ke dalam laut.

3. Tamata sie luaya esi keu me Tuhane eni luma kena kotie loko Alla.

Dua orang dari mereka pergi ke rumah Tuhan untuk memanggil-Nya.

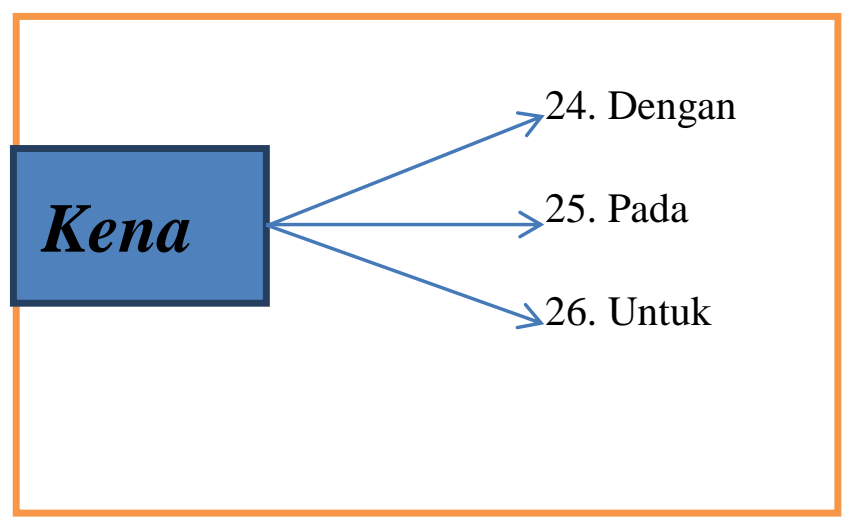

Kata kena memiliki tiga makna di antaranya "dengan", "pada", dan "untuk". Dari ketiga makna dari polisemi kena dalam bahasa Alune ini akan di uraikan konteks yang melatarbelakangi kalimatnya dalam bahasa Alune. Kena artinya dalam bahasa Indonesia iyalah " pada”, konteksnya ketika Yesus memberikan nasihat kepada murid-muridnya tentang berbagai penyesatan yang dilakukan oleh orang-orang yang tidak percaya kepada Allah. Pada makna selanjutnya kena_pun bermakna "untuk" dan "dengan", ke dua makna ini merupakan konjungsi (kata hubung antar kata dalam kalimat) jika di lihat dari unsur morfologinya. Konteks yang ada pada makna "dengan" iyalah bagian perbandingan antara orang kaya yang memakai juba ungu yang mewah "dengan" seorang Lazarus yang berpakaian biasa dan tubuhnya pun penuh dengan kotoran. Sama halnya dengan makna "untuk" pada polisemi kena, konteksnya mengkisahkan tentang perumpamaan antara orang Farisi dan dan pemungut Cukai mereka pergi ke rumah Tuhan "untuk" beribadah kepadaNya. 
Jika kita mengkaji Polisemi kena dari segi konteks, maka akan terlihat bahwa kena yang bermakna "dengan" dan "untuk" merupakan kata hubung antar kalimat, selain itu juga jika kita menganalisisnya maka ketiganya meruapakan, kalimat pembanding yang di tulis dalam ke tiga kalimat tersebut. Kata kena bermakna "pada" karena dalam bahasa Alune kena artinya iyalah "pada", dapat di lihat juga contoh dari kata kena yang bermakna "pada" berikut ini.

Contoh kalimat:

Kena mere pusue tamata esi keu me meite.

Pada waktu itu, semua orang pergi ke Pantai.

Dengan demikian dapat disimpukan bahwa makna kata "pada" juga merupakan kata depan pada sebuah kalimat dan konjungsi antar kalimat, kata.

\section{KESIMPULAN}

Polisemi dalam Alkitab Injil Lukas berbahasa Alune, dapat dibedakan berdasarkan kategori atau kelas kata dan bentuknya, untuk menentukan makna leksikal dan makna gramatikal, dari suatu kalimat yang dilisankan atau tulisannya. Polisemi dalam bahasa Alune pada Kitab Injil Lukas dibedakan atas empat kategori kelas kata yakni; Pronomina, verba, nomina, dan preposisi, yang masing-masingnya memiliki bentuk dasar, dan turunan. Dalam penelitian ini, peneliti mengungkapkan atau menguraikan kasus-kasus polisemi dari keempat kelas kata di atas yakni; esi, sire, ai, hena, kuele, keu, rana, bei, kena, aure, inoake, namake, ibeteke, iriluke, lapune, lumare, dan lokoi. Kepolisemian itu ditentukan dengan melihat adanya hubungan yang dapat merunut pertalian makna leksikal dan makna gramatikalnya.

\section{DAFTAR PUSTAKA}

Aminuddin.1985. Semantik Pengantar Studi tentang Makna. Bandung: Sinar Baru Algensindo

Chaer, Abdul. 2009. Pengantar Semantik Bahasa Indonesia. Jakarta: Rineka Cipta.

Moleong J. Lexy. 2008. Metodologi Penelitian Kualitatif. Bandung: Remaja Rosdakarya.

Makaruku E. 1991, P4 Kena Lepate Alune (P4 dalam Bahasa Alune) Ambon: Departemen Pendidikan dan Kebudayaan.

Sinode GPM, 2007. Matiuse Sou Misete Bei Alla Kena Yesuse Rebe Matiuse Ilekiule. Ambon: Yayasan Sumber Sejahtera.

Takaria D. 2008. Kamus Bahasa Melayu Ambon. Ambon: Dinas Pendidikan dan Kebudayaan Provinsi Maluku.

Wattimuri, E., dkk. 1996. Struktur Bahasa Alune, Jakarta: Departemen Pendidikan dan Kebudayaan. 
Polisemi dalam Kitab Injil Lukas Berbahasa Alune 